PART 3

News and Social History 
John M. Hunt - 9789004276864

Downloaded from Brill.come4/26/2023 09:07:45AM via free access 


\title{
Rumour, Newsletters, and the Pope's Death in Early Modern Rome
}

\author{
John M. Hunt
}

The history of news in early modern Europe has recently become a major focus of scholarly attention. Scholars have investigated the news, both in its printed and manuscript forms, studied the veracity and opinion of news, and located it in the burgeoning scholarship on international affairs and the public sphere. ${ }^{1}$ Although gaining some recent attention, rumours and the local origins of news have been largely neglected by scholars. This study seeks to understand the interplay between rumours and newsletters by interpreting local events in papal Rome during the sixteenth and seventeenth centuries. It will examine the rumours, news, and populace's reading of events leading up to the pope's death.

No event garnered as much attention in Rome as the possibility of the reigning pope's death. The possibility of such event provoked anxiety and excitement among the populace. Romans, both at court and in the city, were astute observers of the pope's health and daily activities. They remained attuned to signs of his imminent death, which included prolonged illnesses, missing important liturgical duties and ceremonies, omens and prognostications, and, above all, the preparations the papal government made to ready the city for an interregnum. This news travelled through rumour and manuscript newsletters

1 The work on early modern news is ever growing. For good introductions to the field and current debates, see Sabrina Alcorn Baron and Brendan Dooley (eds.), The Politics of Information in Early Modern Europe (London: Routledge, 2001); Brendan Dooley (ed.), The Dissemination of News and the Emergence of Contemporaneity in Early Modern Europe (Aldershot: Ashgate, 2010); Joop W. Koopmans (ed.), News and Politics in Early Modern Europe, 1500-1800 (Leuven: Brill, 2005); and Joad Raymond (ed.), News, Newspapers and Society in Early Modern Britain (London: Routledge, 1999). For important monographs, see Filippo De Vivo, Information and Communication in Venice: Rethinking Early Modern Politics (Cambridge: Cambridge University Press, 2007); Brendan Dooley, The Social History of Skepticism: Experience and Doubt in Early Modern Culture (Baltimore: Johns Hopkins University Press, 1999); and Joad Raymond, The Invention of the Newspaper: English Newsbooks, 1641-1649 (Oxford: Oxford University Press, 2005). See also the introduction to this volume. 
called avvisi. ${ }^{2}$ Rumours, spread primarily by word of mouth, can be difficult to trace. Although historians will never have direct access to their oral forms, their echoes can be found in the diaries and newsletters of the city. Newsletters in turn, not only kept rumours alive but also provoked rumours and could influence the content of the oral word. Thus, much of the rumour-mongering and news-gathering concerning the pope's health and death, centred on faceto-face, often oral encounters. ${ }^{3}$

Print played a negligible role in the dissemination of rumour and news concerning the pope's death for a variety of reasons. First, the papacy kept a tight rein over the printing houses of the city, censoring any printed writings injurious to the pope's person and reputation. ${ }^{4}$ Indeed, to publish printed treatises and satires against the pope, one had to find safer havens in Venice and cities outside Italy in Protestant lands. More important was the fact that by the time the news of the pope's death had reached cities beyond Italy and could be printed, it had become old news, already verified in manuscript as false or true. ${ }^{5}$ The most expedient method of keeping abreast of the pope's health was by rumour in Rome and by the newsletters elsewhere in Italy and Europe.

2 On avvisi, see Mario Infelise, "Roman Avvisi: Information and Politics in the Seventeenth Century" in Gianvittorio Signorotto and Maria Antonietta Visceglia (eds.), Court and Politics in Papal Rome (Cambridge: Cambridge University Press, 2002), pp. 212-228; Cesare D’Onofrio, "Gli 'Avvisi' di Roma dal 1554 al 1605", Studi Romani, 10 (1962), pp. 529-548; Brendan Dooley, "De bonne main: les pourvoyeurs de nouvelles à Rome au XVIIe siècle", Annales: Histoire, Sciences sociales, 6 (1999), pp. 1317-1344; and De Vivo, Information and Communication, pp. 80-85. On rumour see Jean-Noël Kapferer, Rumors: Use, Interpretations, and Images (New Brunswick: Transaction Publishers, 1990); James C. Scott, Domination and the Arts of Resistance: Hidden Transcripts (New Haven: Yale University Press, 1990), pp. 144-147; Adam Fox, "Rumor, News, and Popular Public Opinion in Elizabethan and Early Stuart England", The Historical Journal, 40 (1997), pp. 592-620; id., Oral and Literate Culture in England, 1500-1700 (Oxford: Oxford University Press, 2000), pp. 335-405; and Georges Lefebvre, The Great Fear: Rural Panic in Revolutionary France (New York: Pantheon Books, 1979).

3 For the oral nature of rumours and news, see Massimo Rospocher and Rosa Salzberg, "An Evanescent Public Sphere: Voices, Spaces, and Publics in Venice during the Italian Wars" in Massimo Rospocher (ed.), Beyond the Public Sphere: Opinions, Publics, Spaces in Early Modern Europe (Bologna: Il Mulino, 2012), pp. 93-114; Elizabeth Horodowich, Language and Statecraft in Early Modern Venice (Cambridge: Cambridge University Press, 2008), pp. 126-164.

4 Infelise, "Roman Avvisi," pp. 212-214. On church censorship in Italy, see Gigliola Fragnito, "The Central and Peripheral Organization of Censorship" in Gigliola Fragnito (ed.), Church, Censorship and Culture in Early Modern Italy (Cambridge: Cambridge University Press, 2001), pp. 13-49.

5 Andrew Pettegree, The Book in the Renaissance (New Haven: Yale University Press, 2010), pp. 340-341; Ian Atherton, "The Itch Grown a Disease: Manuscript Transmission of News in 
This chapter will also examine the local nature of news by contextualizing it among the events, often ritualized, which sparked off rumours of the pope's death in Rome. News of the pope's death interested a variety of people. Romans looked forward to the liberty of sede vacante, the period between the pope's death and the election of his predecessor: avengers plotted assaults against enemies with the cessation of papal law during the vacancy; magistrates of Rome's civic government - the Popolo Romano - anticipated increased jurisdictional authority with the waning of papal law; and the city in general eagerly awaited the papal election that would initiate a new regime. ${ }^{6}$ If the pope enjoyed a bad reputation, the populace stirred with glee at the prospect of rebelling against his regime by assaulting his statue located at the Capitoline Hill. In this context, misinformation remained supreme as rumours, halftruths, and outright lies played on the populace's hopes and fears, provoking a great deal of turmoil and chaos in the streets of Rome.

Rumours of the pope's death kept Rome on edge. The imminent death of the pope sparked rampant murmured discussion among the populace, which remained attuned to any signs that the pope's reign was at an end. ${ }^{7}$ This discussion, fed by rumour, the newsletters, and the court gossip of papal servants and ambassadors, in turn increased the widespread belief in a looming sede vacante. Much of the public discussion focused on the pope's poor health. Persistently ill popes stimulated the fears and hopes of Romans as they waited for a sede vacante that could take months, sometimes even years, to come, as popes, typically elected as old men, often suffered from a myriad of ailments and illnesses. The pope's health was thus a recurrent topic of public interest. This can be gleaned from the deluge of newsletters that discussed the prolonged illnesses of Paul IV in 1558-1559, Sixtus V in 1590, and Clement VIII in 1604-1605. ${ }^{8}$ These microscopic lenses directed at the pope's health often

the Seventeenth Century" in Raymond (ed.), News, Newspapers, and Society in Early Modern Britain, pp. 40-42.

6 On sede vacante, see Laurie Nussdorfer, "The Vacant See: Ritual and Protest in Early Modern Rome", Sixteenth Century Journal, 18 (1987), pp. 173-189; ead., Civic Politics in the Rome of Urban VIII (Princeton: Princeton University Press, 1992), pp. 228-253; John M. Hunt, "Violence and Disorder in the Sede Vacante of Early Modern Rome, 1559-1655" (PhD thesis, Ohio State University, 2009).

7 For rumours of the deaths of the long-lived monarchs Henry VIII and Elizabeth I in sixteenthcentury England, see Fox, Oral and Literate Culture, pp. 357-360.

8 For Paul IV and Clement VIII, see Ludwig von Pastor, The History of the Popes from the Close of the Middle Ages, 40 vols (London: Kegan Paul, 1891-1953; hereafter HOP), vol. 14, p. 413; vol. 24, pp. 432-434. For Sixtus V, see Biblioteca Apostolica Vaticana (hereafter BAV), Urbinate Latina (hereafter Urb.lat) 1058, avvisi of 11 and 25 August 1590, fols $407^{\mathrm{r}}$ and $428^{\mathrm{r}}$. 
inspired false reports of his death. Newsletter writers and ambassadors wrote about the rumours surrounding Innocent X's poor health and several tumbles he took throughout 1654. This discussion gave rise to the belief that he had died in early January 1655 - just days before his actual death - and inspired papal servants to steal the ill pope's household possessions, including his favorite soup bowl. The servants eagerly anticipated taking part in a venerable tradition of pillaging the household possessions of the dead pontiff. ${ }^{9}$

Eager for the freedoms of the sede vacante, Romans were astute observers of the pope's daily activities. His failure to perform his duties as the supreme pontiff and bishop of Rome were tell-tale signs of his imminent death. Pius V was so feeble for much of early 1572 that he could not say mass on Sundays, provoking rumours of his approaching death (which actually occurred on the first of May of that year). ${ }^{10}$ The gentleman diarist Giacinto Gigli recorded every illness that beset Innocent X, noting in particular when the pope failed to meet the newly elected officials of the Popolo Romano in August 1651 and, later, when he holed himself up in the papal palace at the Quirinal Hill for the entire month of August 1654. These events provoked rumours and whispered murmurs among the people. ${ }^{11}$

Failing to perform sacred duties on important feast days was particularly disconcerting to the city. In 1622 rumours raced through Rome when poor health forced Gregory XV to skip the bestowal of dowries to poor girls that took place every Annunciation at Santa Maria sopra Minerva. Likewise, Gigli recorded that the people read signs of Urban VIII's coming death when he did not attend to his ceremonial duties on Ascension and Corpus Christi in $1643 .{ }^{12}$

Many ill popes sought to hide their poor health by continuing to perform their sacred duties as the Vicar of Christ. Both Paul IV and Pius IV, despite their

9 Archivio di Stato di Venezia (hereafter ASVe), Dispacci degli ambasciatori al senato, Roma, filza 136, dispatch of 5 January 1655 , fols $605^{\mathrm{v}}-606^{\mathrm{r}}$. For another example of observers concluding that the pope was near to his death, see the anonymous conclave report translated into English, The Last Conclave (London: Stephen Bulkley for Henry Seile, 1642), wherein the author writes "In the beginning of the yeare 1623 the indisposition of the Pope [Gregory XV] was so apparent that all men did foresee that it would not belong before the Roman court received a change in the government," sig. A6 ${ }^{v}$. On ritual pillages, see Carlo Ginzburg, "Ritual Pillages: A Preface to Research" in Edward Muir and Guido Ruggiero (eds.), Microhistory and the Lost Peoples of Europe (Baltimore: Johns Hopkins University Press, 1991), pp. 20-41.

10 Pastor, $H O P$, vol. 18, p. 455.

11 Giacinto Gigli, Diario di Roma, ed. Manlio Barberito, 2 vols (Rome: Colombo, 1994), vol. 2, pp. 636, 712 .

12 Gigli, Diario, vol. 1, pp. 102, 308. 
fragilities, performed their duties until their deaths. Pius IV, although weak throughout much of 1565, still managed to celebrate Easter mass at St. Peter's. The Tuscan ambassador Ugolino Grifoni reported that Pius "sang it with a voice so clear and sonorous that he put to shame Cardinal Vitelli," who had assisted him during the mass. ${ }^{13}$ Despite this subterfuge, rumours swirled about Pius's health and death for the rest of the year. Pasquinades - handwritten invectives - appeared on the ancient statue, Pasquino, and throughout the streets and squares, mocking Pius's attempts to hide his illness. One wondered:

Has he died or has he not? Has he grown worse?

Is he getting worse or not?

Now he has gotten better.

He has lost his speech. Now he has lost the use of arms. ${ }^{14}$

Similarly, Gregory XIII tried to conceal his long illness of 1581, but his condition became so serious that he could not carry out his sacred functions for much of the year, causing excitement about his certain death..$^{15}$ In January 1644 , several months before his death, Urban VIII attempted to keep his ailing health a secret, but rumours of his death were so rampant that the conservators of the Popolo Romano locked and fortified the windows and doors of their palace where the statue of the much-hated Barberini pope was kept. They took these actions "to ward off any disorder that could happen." ${ }^{16}$ They were seeking to

13 Pastor, $H O P$, vol. 14, p. 413; vol. 16, p. 398. For Pius IV and Cardinal Vitellozzo Vitelli, see Medici Archive Project, http://documents.medici.org; Archivio di Stato di Firenze (hereafter ASF), Carteggio universale, vol 515, letter of 23 April 1565, fol. 376 .

14 Valerio Marucci, Antonio Marzo, and Angelo Romano (eds.), Pasquinate romane nel Cinquecento (Rome: Salerno, 1982), no. 722, p. 931. The fluctuating health of Alexander VII during the last year of his pontificate (1667) inspired similar pasquinades; see Gregorio Leti, Il Sindicato di Alessandro VII (s.l., 1667), pp. 55-58. For example, Leti copied this pasquinade into his account of Alexander's death: "Is the pope dead? Is he alive? | God keeps him for a hundred hours | The Pope as our lord | He has his life and his death in his hand [...] | To trick the Christian people by always being moribund, and never dying."

15 BAV, Urb.lat 1049, avviso of 16 April 1581, fol. 324 . Gregory XIII recovered later that year, but remained in poor health throughout his pontificate, which lasted until 1585. See Pastor for continual concerns over his health, $H O P$, vol. 20, p. 633. For concerns about the pope's health in anticipation of a trip to Bologna and the possibility of his death while he was away from Rome, see BAv, Urb.lat 1052, avvisi of 14 and 18 January 1584, fols $17^{\mathrm{rr}}, 21^{\mathrm{r}}$.

16 Gigli, Diario, vol. 1, p. 412. Gigli also recorded that Innocent X "kept hidden" his ill health, even among members of his court, by attending a consistory on 16 March 1654; see vol. 2, p. 702 . 
prevent a crowd of angry Romans from assaulting the statue in vengeance for his high taxes on bread and wine.

Popes frequently made public appearances to quell rumours of their deaths. In November 1602, Clement VIII appeared at the balcony of the Vatican palace to give the people a show of his good health. ${ }^{17}$ But these demonstrations often backfired, spurring even more gossip and rumour. On 27 March 1644, Urban VIII attempted to give an Easter benediction from a window overlooking St. Peter's Square rather than the customary location, the portico of the church. It was rumoured that Urban was so weak that when servants dressed the pope for the occasion, "it was necessary to unstitch the sleeves of his gown and throw it over him without moving his arms" for fear that the ordeal might kill him. ${ }^{18}$ The servants had to prop up the pope as he gave his benediction - a sight that did not instill confidence in the people.

Omens could also give rise to rumours among Romans, who were always looking for signs of the pope's death. Despite Paul IV's attempts to keep his dropsy a secret during the summer of 1559 , news of illness reached the populace, and by 17 June a rumour - one of many that summer - spread of his death. The appearance of a comet that night over the Vatican further convinced the city that he had died. ${ }^{19}$ A similar episode occurred near the end of Pius IV's pontificate. Although he performed his ceremonial and sacred duties throughout the year, his fragility became apparent to the people, who believed that he would not see the New Year. This rumour gained support because on 2 December 1565, the first Sunday of Advent, a candle nearest to the papal throne went out twice for no apparent reason. ${ }^{20}$

Sixtus V attracted a deluge of omens as he neared death. The Savoyard ambassador Carlo Muti reported that the papal court talked of a black bird that appeared at the pope's windowsill as he lay on his deathbed, and only flew away after the pope had died. At the same time, the clear day suddenly turned stormy, casting the sky with lightning as the pope approached death. At the hour of Sixtus's death a lightning bolt supposedly struck his family's coat-of-arms that had been placed above the entrance of the Jewish ghetto.

17 Pastor, $H O P$, vol. 24, p. 432.

18 Gigli, Diario, vol. 1, p. 414.

19 BAV, Urb.lat 1039, avviso of 17 June 1559, fol. 49r. See also Pastor, HOP, vol. 14, pp. 411413. An avviso of 8 July 1559 gave Paul IV two weeks to live and noted that the city and court were abuzz with talk of upcoming conclave; see BAV, Urb.lat 1039, fol. 58v . A solar eclipse supposedly foretold Innocent IX's death after a long illness on 20 December 1591; see BAv, Urb.lat 1060, avviso of 1 January 1592, fol. $2^{\mathrm{v}}$. 
The ambassador wrote that immediately there arose "such a discourse among the people who accorded the events so many sinister interpretations."21

Urban VIII's long pontificate engendered many rumours based on omens and on astrologers' predictions of his death. A lunar eclipse of January 1628 and solar eclipses of December 1628 and January 1630, supported by the prognostications of astrologers, all generated rumours of his death. Urban, an affirmed believer in the efficacy of astrology and the malefic effects of the stars on human health and state affairs, had recourse to the counter-magic of the magus Tommaso Campanella. ${ }^{22}$

As the example of Urban VIII reveals, prognostications of the pope's death were quite common and sparked rumours in the city and court. ${ }^{23}$ In 1581, amid rumours and concerns about Gregory XIII's health, an astrologer predicted that the pope would die on October 16 - a prediction that ultimately proved false as Gregory lived until 1585. Nevertheless it fueled further rumours. ${ }^{24}$ Although Clement VIII enjoyed good health in 1599, astrologers prophesied his death that year, prompting many to believe them. ${ }^{25}$ More than forty years later, during the severe flooding of the Tiber in December 1647, inquisitors jailed an astrologer for predicting that once the flood waters receded, Innocent $\mathrm{X}$, who was suffering from gallstones, would die. The prognostications were most likely prompted by political factors since many Romans felt Innocent had failed to respond adequately to the famine that struck the city that year. ${ }^{26}$

The rumours that astrology engendered could be felt beyond Rome. In May 1630, Orazio Morandi, a Vallombrosan abbot in Rome, prophesied that Urban would die from the harmful celestial influences of a solar eclipse. Newsletter writers immediately picked up on Morandi's prognostication. Soon it was disseminating not only throughout the streets of Rome by word of mouth, but eventually throughout Italy and beyond the Alps via newsletters. Other astrologers started predicting Urban's death as Morandi's prophecy became known. The false news of Urban's death acquired so much credence

21 Archivio di Stato di Torino, Carteggio diplomatico, mazzo 11, no. 189, dispatch of 31 July 1590.

22 Daniel P. Walker, Spiritual and Demonic Magic from Ficino to Campanella (University Park, PA: Pennsylvania State University, 2000 [1959]), pp. 205-207.

23 On prophecy and prognostications in early modern Italy, see Ottavia Niccoli, Prophecy and People in Renaissance Italy, trans. Lydia G. Cochrane (Princeton: Princeton University Press, 1990).

24 Pastor, $H O P$, vol. 20, p. 633.

25 Pastor, $\mathrm{HOP}$, vol. 24, p. 431.

26 Gigli, Diario, vol. 2, p. 509. 
through handwritten and printed avvisi that Spanish and German cardinals outside of Rome made ready to travel to the conclave to take part in the papal election. ${ }^{27}$

Papal relatives and officials concerned themselves with keeping the details of the pope's health a state secret because they knew a mere rumour of the pope's death could stir disorder in Rome, as Romans eagerly anticipated the license that ensued with the onset of the sede vacante. For example, when Pius IV was rumoured to have died during the night of 6 December 1565, the city erupted in a spate of violence associated with sede vacante and its vendettas. A few criminals even escaped as papal police were transferring murderers and other hardened prisoners from the city's jails to Castel Sant'Angelo. ${ }^{28}$

Papal authorities also feared the ritual looting that often took place in the wake of the pope's death. When rumours spread throughout the city that Sixtus V had died on 11 July 1590, the Jewish vendors who were gathered at the Wednesday market in Piazza Navona "gathered their goods and fled toward the ghetto to save themselves from pillaging," which in turn only "gave rise to a rumour that the pope had died." The incident caused many to flee from the streets and to lock their palaces out of fear of pillaging and violence. ${ }^{29}$ Later that week, the ailing Sixtus left the palace on the Quirinal Hill to say mass "in order to allow himself to be seen" by the people. ${ }^{30}$ The Governor of Rome had several Jews imprisoned and tortured for sparking the rumour. A little more than a year later, the Jewish merchants fled the market at the Banchi on 15 September 1591, "retreating to their seraglio due to a certain rumour that ran

27 The rumours provoked by Morandi's prophecy sparked "many discussions in writing that dealt with the election of the new pope as if it were sede vacante," which then caused the Spanish and German cardinals to prepare for their journeys to Rome. See an avviso of 18 May 1630 in the appendix of Luigi Amabile, Fra Tommaso Campanella, la sua congiura, i suoi processi e la sua pazzia, 3 vols (Naples: Morano, 1882), vol. 2, p. 149. See also Brendan Dooley, Morandi's Last Prophecy and the End of Renaissance Politics (Princeton: Princeton University Press, 2002).

28 BAV, Urb.lat 1040, avviso of 9 December 1565, fols $148^{\mathrm{rv}}$.

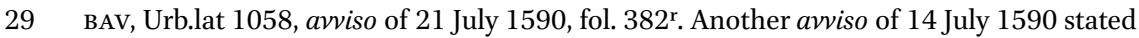
that the Jews "who found themselves in the market of Piazza Navona, fearing that they might be pillaged, suddenly boxed up their merchandise, returning in a hurry to the Ghetto on account of a rumour that spread among them concerning the pope's death" see BAV, Urb.lat 1058, fol. 356 . On the pillages that took place after the pope's death, see Carlo Ginzburg, "Ritual Pillages" in Muir and Ruggiero (eds.), Microhistory and the Lost Peoples of Europe, pp. 20-41.

30 BAV, Urb.lat 1058, avviso of 21 July 1590, fol. $382^{\mathrm{v}}$. 
among the people concerning the interregnum." ${ }^{31}$ The rumour started as public talk centring on a conjunction of events: Gregory XIV's moribund condition and the condemnation of six prisoners to death, which signaled to the populace that the pope's end was near. ${ }^{32}$ Generally the most nefarious criminals were either sent to the highly fortified dungeons of Castel Sant'Angelo or were executed, before the general pardon of minor criminals - petty thieves and debtors - that occurred at the pope's death. Evidently, the people read into the executions that Gregory had died. Gregory, however, lived for another three weeks, during which time daily rumours of his death kept the city in a constant state of anxiety. During this time, seven hundred bandits from the Marches and Abruzzo descended upon the Roman countryside. The leader of one of these bands of brigands claimed that that his group "had heard of the pope's desperate health and during the sede vacante they wanted to try their luck and see what they could do." ${ }^{33}$ They specifically expressed a desire to pillage the property of the Roman Jews.

The circulation of rumours and false news could also inspire rebellion among the civic magistrates - the Popolo Romano - who always eagerly anticipated the sede vacante as an opportunity to exercise unaccustomed power with the cessation of papal law and the acquirement of new jurisdictional authority. False reports of Gregory XIV's death prompted the recently elected conservators and caporioni (leaders of the civic watch) to rush to the Capitoline to attend the general council where important decisions regarding the regulation of the city during the interregnum would be decided. The cardinal chamberlain Enrico Caetani had to give word to the magistrates that the pope was still alive. ${ }^{34}$

This desire for power infected all the officials of the Popolo Romano. In 1605, amid rumours of Clement VIII's death, a newsletter reported that:

such is the desire of some, both the wicked and the foolish, that His Holiness be finished, and so it seems that among these was the caporione

31 BAV, Urb.lat 1509, pt. II, avviso of 28 September 1591, fol. $275^{r}$. Roman writers often used seraglio, meaning an enclosure, interchangeably with ghetto to refer the enclosed quarter of the Jews.

32 An avviso of 25 September 1591 reported that "This evening in Banchi there was a great racket among the Jews who fled in a hurry, speaking of the pope's death" - see BAV, Urb.lat 1059, pt. II, fol. 272r ${ }^{\text {r }}$ Banchi was the financial district of Rome, located on the eastern bank of the Tiber River, near the Ponte Sant'Angelo.

33 BAV, Urb.lat 1059, pt. II, avviso of 9 October 1591, fol. 303v.

34 BAV, Urb.lat 1059, pt. II, avviso of 2 October 1591, fols $289^{\mathrm{v}}-290^{\mathrm{r}}$. 
of Campo Marzo, who pulled out the standard [of his rione, or quarter], as if it were sede vacante. ${ }^{35}$

Similarly, the day after Paul V fell sick on 15 January 1621, rumour spread through Rome that he had died of a stroke. Gigli wrote that:

the following morning $[\ldots]$ the entire city was stirred up, and the caporioni opened all the prisons and freed those that were there for civil matters [...] and the people began to make a ruckus as if it were sede vacante. $^{36}$

Gigli, the caporioni of Campitelli, knew well that the Popolo Romano and, in particular, the caporioni cherished this right to administer power and patronage as the ones to open the prisons at the onset of the pope's death.

Rumours could feed the wishful thinking on the part of the officials of the Popolo Romano. In 1559, after hearing rumours of the death of Paul IV, a stern pope whose policies had alienated the populace, the magistrates assembled in the Palace of the Conservators where they:

after having said a thousand evils against the pope, resolved to bust open all the prisons and, in particular, Ripetta, that is the prison of the Inquisition. ${ }^{37}$

By venerable and unwritten custom, the Popolo Romano had the right to free all debtors and criminals in civil matters imprisoned in the city's main jails - the Tor di Nona, the Corte Savella, the Borgo, and the Capitoline prison. However, not only did the magistrates use the rumour of the pope's death to claim their traditional right, they also took the unprecedented step of freeing heretics condemned in the dungeons of the Inquisition. Nevertheless, they were true Catholics, having the heretics swear upon their release to live according to the doctrines of the Church. Thus, their actions were motivated by power more than by any sympathy for Protestantism. The Inquisition was an institution associated with Paul IV; as a cardinal he had directed its activities with unrestrained energy and enthusiasm. The actions of the magistrates sparked

35 BAv, Urb.lat 1073, avviso of 26 February 1605, fols $90^{\text {rvv. }}$.

36 Gigli, Diario, vol. 1, p. 80.

37 BAV, Barbarini Latini 5243, “Diario di Vincenzo Belli,” fol. 161․ See also BAv, Urb.lat 1039, avviso of 21 August 1559, fol. 73 . The prisons of the Inquisition were located on via Ripetta, the street leading to one of Rome's two river ports. 
further rumour of the pope's death, prompting the people of Rome to sack the warehouses and prisons of the Inquisition. ${ }^{38}$

The very actions that the pope, his family, and his government took to prepare for the coming sede vacante, only contributed to the birth of rumour and confusion. As Pius IV lay indisposed in bed, the cardinal-nephew and the governor of Rome had the city gates locked to keep bandits and assassins from entering the city. Because of this preventive measure, the people "took it that [Pius] was dead."39 The introduction of troops, stationed at the gates to protect the city and at the conclave, was also seen as a sign that the pontiff was near death or had died. For example, a newsletter of 23 February 1605 reported that Clement VIII:

was about to die because another company of Corsican soldiers, who were outside [the city], was ordered into Rome, and on Monday additional weapons [...] were extracted from Castel Sant'Angelo to arm them. In addition, Cardinal San Giorgio had closed and walled up some of the spaces in the Palace of Alessandro where he stays in the summer. ${ }^{40}$

Two weeks later, another newsletter observed that Clement's family the Aldobrandini - had placed guards at the palace of the pope's niece and at their villa in Frascati, which its writer concluded was a "bad sign."41 Furthermore, the pope's family had their valuables removed from the villa, "just as is done during sede vacante," a reference to the pillaging that sometimes accompanied a pope's death. ${ }^{42}$ These were necessary precautions because bandits from Abruzzo - getting wind of rumours of Clement's death - had marched toward Frascati and its environs with the hope of plundering the villa.

The preparations of cardinals to protect their palaces from ritual pillages were also signs of the pope's death. The Tuscan ambassador Curtio Picchera noted amid the rumours of Gregory XV's death that the Cardinal of Savoy had hired a mercenary captain from the Città di Castello with a hundred soldiers to

38 BAV, Barb.lat 5243, "Diario di Vincenzo Belli," fols $161^{\mathrm{v}}-62^{\mathrm{r}}$ and BAV, Urb.lat 1039, avviso of 19 August 1559, fol. $71^{\mathrm{r}}$.

39 BAV, Urb.lat 1040, avviso of 9 December 1565, fols $148^{r-v}$.

40 BAV, Urb.lat 1073, avviso of 23 February 1605, fol. 86v . Cardinal San Giorgio refers to Cinzio Aldobrandini, the nephew of Clement VIII.

41 BAV, Urb.lat 1073, avvisi of 2 and 5 March 1605, fols 97 ${ }^{\mathrm{r}}, 124^{\mathrm{r}}$.

42 BAv, Urb.lat 1073, avviso of 23 February 1605, fol. 86v. 
watch his palace at Monte Giordano. ${ }^{43}$ The Dutch newsletter writer and émigré, Teodoro Ameyden, cited Cardinal Mario Theodoli's sudden recourse to armed men to guard his palace and person as proof of Urban VIII's impending death on 29 July $1644 .{ }^{44}$

The most visible sign of the pope's approaching death was the Governor of Rome's transference of the "most important prisoners" - the oft-used phrase of official reports and newsletters - from the city's many jails to the iron-tight dungeons of Castel Sant'Angelo. ${ }^{45}$ This euphemism meant not only dangerous prisoners such as bandits and murderers, but those guilty of capital crimes (such as forgery and treason) and heresy. The governor had these prisoners moved to Sant'Angelo because the Popolo Romano exercised the right to open the four main prisons of the city, freeing all those held for petty offenses (theft, gambling, and debt).

The decision to have the prisoners transferred, generally made by the cardinal-nephew, was a difficult one to make since suspicions were quickly roused once the populace saw the procession of shackled prisoners making its way in the dead of night to Castel Sant'Angelo. It was made only once the pope's condition was considered hopeless. Nevertheless, it was one that the cardinal-nephews and papal officials agonized over, delayed, and kept secret.

43 ASF, Archivio mediceo del principato 3338, dispatch of 7 July 1623, fol. $466^{\text {r }}$. See also Picchera's hasty letters concerning Gregory's health in early July; dispatches of 3 and 4 July 1623 , fols $445^{r}$, $463^{r}$.

44 Biblioteca Casantense, cod. 1832, "Diario della città e corte di Roma notato da Deone hora temi Dio," fol. 102 r. On the ritual pillages, see footnote 27. On the defenses of cardinals against the pillages, see John M. Hunt, "Violence and Disorder in the Sede Vacante," pp. 122-172. The cardinals fortified their homes against looting after the pope died, but also in case a rumour arose from the conclave that one of them had been elected pope. Romans claimed a customary right to pillage the pope-elect's palace.

45 For the prisons of Rome, see Antonio Bertolotti, Le prigioni di Roma nei secoli XVI, XVII e XVIII (Rome, 1890). For the Tor di Nona, see Alberto Cametti, "La torre di Nona e la contrada circostante dal medio evo al secolo XVII", Archivio della società romana di storia patria, 39 (1916), pp. 411-466. For the prisons of the Corte Savella, see Niccolò Del Re, Il maresciallo di Santa Romana Chiesa (Rome: Istituto di studi romani, 1962), pp. 30-33. For the Capitoline prisons, see Emmanuel Rodocanachi, The Roman Capitol in Ancient and Modern Times, trans. Frederick Lawton (London: William Heinemann, 1906), pp. 106, 160-166. For the jails of the Governor of Borgo, see Niccolò Del Re, "Il governatore di Borgo", Studi romani 11 (1963), pp. 21-22. For the dungeons of Castel Sant'Aneglo, see Emmanuel Rodocanachi, Le château Saint-Ange (Paris: Hachette, 1909). The prisons of the Tor di Nona were located near the north bend of the Tiber River. Those of the Corte Savella were located at the western end of the Via Giulia, and those of Borgo near Santa Maria Traspontina, outside the Vatican. 
For example, the cardinal-nephew of Clement VIII waited until his uncle suffered a stroke before having the serious prisoners removed the next day to the secure jails of Castel Sant'Angelo. ${ }^{46}$ Eighteen years later the family of Gregory $\mathrm{XV}$ attempted to hide his protracted illness. However, once he neared death, a newsletter reported that "already the house Ludovisi was seen in mourning and the prisoners had been sent to Castel Sant'Angelo in great numbers," and that "two squadrons of Corsican soldiers were present at the palace of the Ludovisi." 47

Confusion could reign during this transitional phase. The Pamphili family had the prisoners moved to Castel Sant'Angelo after Innocent $\mathrm{X}$, suffering from bladder problems and developing a fever, "was held dangerously close to death." ${ }^{48}$ Innocent lived for another four years, but the prisoners' transfer sparked rumours of his death and resulted in a spate of violence among the populace. Thus papal families typically waited until the last minute to make this decision to avoid confusing the populace and spreading rumours. When the Governor of Rome asked Cesare Facchinetti - the cardinal-nephew of the ailing Innocent IX - about moving the prisoners of importance in January 1592, Facchinetti responded that "Innocent was in good condition" and that "it would be far worse if his condition were made public."49 The decision was delayed, and Innocent died a few days later before the prisoners could be moved, which caused even more chaos when hardened criminals escaped as the caporioni opened the city's jails.

Newsletters facilitated the dissemination of observations from the court and the rumours from the streets, not only in Rome but throughout all of Italy and Europe. Even old rumours traveled beyond Rome in avvisi and sometimes

BAV, Urb.lat 1073, avviso of 5 March 1605, fol. 123․

BAV, Urb.lat 1093, undated avviso, fols $524^{\text {rvv. }}$. For other examples, see BAV, Urb.lat 1059, pt. II, avviso of 5 October 1591, fol. 300r: "other prisoners were transported to Castello on the occasion of the illness of the pope." Gregory XIV had been ill for most of his pontificate. Since he grew increasingly feeble in the autumn of 1591, his cardinal-nephew Emilio Sfondrati had the nefarious criminals moved to the papal dungeons almost two weeks before his death on 16 October. When Urban VIII, who had been ill with dysentery and catarrh, grew worse on the morning of 27 July 1644, his cardinal-nephew Francesco Barberini ordered the prisoners removed to Castel Sant'Angelo two evenings later. See Archivio Vaticano Segreto, Segretario di Stato, Avvisi di Roma, t. 96, avviso of 30 July 1644, fol. $203^{\mathrm{r}}$ and ASVe, Dispacci, Rome, filza 121, dispatch of 30 July 1644, fol. $44^{\mathrm{r}}$.

48 Gigli, Diario, vol. 2, p. 632. The cardinal-nephew, Camillo Pamphili, also had a million scudi and other treasures moved from the papal palace on Quirinal to the family palace in Piazza Navona (perhaps from a fear of looting). 
in printed form, as the prophecies of Orazio Morandi demonstrate. Papal authorities attempted to curtail the activities of the newsletter writers, particularly those who wrote on sensitive political information centring on the papal court and policy, including the pope's health, always a major concern for the powers of Italy and Europe. In 1571 Pius V had several newsletter writers arrested and some even hanged. A year later he promulgated the constitution Contra scribentes, exemplantes et dictantes monita vulgo dicta gli avvisi e ritorni, which banned writings that defamed the pope and other prominent men or that spread rumours and predictions of the pope's death. Pius V's successors renewed these bans, which forced many newsletter writers to produce more clandestine news pieces called avvisi secreti whose contents nonetheless became known to a greater public. All papal officials could do was to make examples of the few newsletter writers who happened to fall into their grasp. ${ }^{50}$ For example, the Governor of Rome sentenced the newsletter writer known as Luperzio to life imprisonment after he spread the news of Gregory XIII's poor health in $1581 .{ }^{51}$

Popes hounded astrologers as well. On 15 July 1630, Urban VIII, both frightened and angered by the whirlwind of predictions concerning his death, had Morandi and other astrologers arrested and jailed. Gigli noted that Urban had singled out Morandi, who had "written discourses and letters, which blasphemed the eminence of the title given to the pope by the cardinals and sent them to various places." ${ }^{52}$ Yet Urban also sought out other astrologers, as well as the scribes who copied their predictions in the newsletters. A year later, Urban, still roiling from the rumours of his demise, issued the bull Inscrutabilis, which forbade the prediction of the deaths of popes and other prelates on the pain of death. Ecclesiastics, like Morandi, who accounted for the majority of astrologers, would lose their clerical status if they made prophecies of any kind concerning the pope..$^{53}$

Despite the efforts of the papacy to silence rumours and their primary disseminators - newsletter writers and astrologers - news of the impending death of the pope, whether true or false, continued to spread among the people. The pope could not stop his subjects from commenting on his health and

50 Infelise, "Roman Avvisi," pp. 214-215. The English title of the constitution is "Against writers, copiers and speakers of news called in the vulgar avvisi e ritorni."

51 BAV, Urb.lat 1049, avviso of 21 October 1581, fol. 399v.

52 Gigli, Diario, vol. 1, p. 195. Morandi later died in prison from poisoning, most likely the victim of assassination. See also Dooley, Morandi's Last Prophecy, pp. 162-179.

53 Luigi Tomassetti (ed.), Bullarum, diplomatum et privilegiorum, t. 14 (Turin: Dalmazzo, 1868), p. 211. 
his daily activities. Rumours reflected a desire among Romans of all ranks to shape and control the social and political world around them. Rumours, as sociologist Jean-Noël Kapferer has argued, "convey information, we want to believe. Our desire to believe is sometimes our usual criteria of realism and plausibility." 54

Many popes, especially those who imposed excessive taxes or ruled severely, angered the populace enough for it to wish for an end to their reigns. Paul IV, Sixtus V, and Urban VIII stand out as the most extreme examples of this kind of pope. Romans also desired the pope's death because it would initiate the sede vacante, a time of license between his death and the election of his successor. Some hoped to profit during the vacancy through burglary, others sought revenge against their enemies and rivals. Merchants and bankers, who wagered on the lengths of pontificates, anticipated windfalls from a successful prediction of a pontiff's death. ${ }^{55}$ The Popolo Romano, as we have seen, acquired increased jurisdictional authority during the sede vacante.

Boredom, or the desire for change, was also a motive for the populace to anticipate the pope's death. In the case of long pontificates, such as the sixteen-year reign of Paul V, the people, especially those with connections to the papal court, simply desired a new pontificate that would open the doors of patronage to a different set of officials and prelates. Despite Paul V's popularity in Rome for keeping the people fed with bread, Gigli wrote concerning his death that:

In sum he was worthy of reigning much longer for his virtues, even if the mob seemed annoyed with the length of this period [i.e. his reign] for no other reason than it desired new things. ${ }^{56}$

$54 \quad$ Kapferer, Rumor, pp. 82-84, 82.

55 The practice had become so prevalent that Gregory XIV banned it along with wagering on papal elections in a bull of 21 March 1591. Gregory XIV issued an Italian translation so that bankers and gamblers could read it; see Beinecke Rare Book and Manuscript Library, Yale Library, "Bolla della Santita di N. S. Gregorio PP XIV contra chi fà scommesse sopra la vita \& morte ò sopra la futura elettione del Pontefice Romano ò sopra le promotioni dei Cardinali della Santa Chiesa Romana." For wagering on the election, see John M. Hunt, “The Conclave from the 'Outside In': Rumor, Speculation, and Disorder in Rome during Early Modern Papal Elections", Journal of Early Modern History, 16 (2012), pp. 355-382.

56 Gigli, Diario, vol. 1, p. 80. After the death of Gregory XV, Gigli remembered the disappointed hope the people had for Paul's successor: "When he assumed the papacy there was an incredible expectation that the people had of him [...]. [The populous], desirous of new things, was annoyed by the length of the pontificate of Paul V. But in the shortest time they realized how they had been tricked," p. 120. Similarly, the Mantuan 
At the local level, rumour - whether spread by word of mouth or through newsletters - served to inform Romans of the pope's health and possible death. These rumours had their origins in observations of the pope's daily activities and health. As the health of ailing popes became worse, Romans began to look for the tell-tale signs of their death. These included moving dangerous criminals to the more secure prison of Castel Sant'Angelo, preparing the city for the violence of the sede vacante, and fortifying family palaces and holdings. This information was best conveyed - while it was fresh - through rumour and newsletters. Even without papal censorship, by the time the news made it to print, it would have been old news, verified by events at the papal court and in the city. News was best spread in Rome through oral channels, although stimulated by visual and often ritual cues.

Rumours of the pope's death fulfilled several desires of the Roman people. They were a form of political discourse in which Romans commented on the policies of the reigning pope. ${ }^{57}$ But more than that, rumours reflected the eagerness of the city for the sede vacante, during which all sorts of social and political agenda, ranging from personal vengeance to protests against dead popes, could be executed. Whatever their origin or the motives behind them, rumours allowed many of those barred from the halls of power to voice their opinion and in some cases allowed them to shape the world around them. In this regard, rumours served as one example of the many "weapons of the weak" outlined by James C. Scott in Domination and the Arts of Resistance. ${ }^{58}$ The power of rumour can be seen in the fear it instilled in papal authorities and in their efforts to stifle the spread of reports of the pope's ill health and death.

ambassador Giovanni Battista Tarabucci noted in a dispatch of 20 May 1643 that, after twenty years of Urban VIII's pontificate, Romans "were eager for change," see Pastor, $H O P$, vol. 28, p. 402.

57 Ethan H. Shagan, "Rumors and Popular Politics in the Reign of Henry VIII" in Tim Harris (ed.), The Politics of the Excluded, c. 1500-1800 (New York: Palgrave, 2001), pp. 39-66.

58 Scott, Domination and the Arts of Resistance, p. 147. 